\title{
Amphibians in an urban environment: a case study from a central European city (Wrocław, Poland)
}

\author{
Agnieszka Konowalik ${ }^{1}$ - Anna Najbar ${ }^{2} \cdot K$ Kamil Konowalik ${ }^{3} \cdot$ Łukasz Dylewski $^{4}$ Marzena Frydlewicz $^{5} \cdot$ Paweł Kisiel $^{5}$. \\ Agata Starzecka ${ }^{6} \cdot$ Anna Zaleśna $^{5} \cdot \mathrm{Krzysztof} \mathrm{Kolenda}^{2}$ iD
}

Published online: 30 November 2019

(C) The Author(s) 2019

\begin{abstract}
In 2016, we studied the occurrence of amphibians in 231 selected ponds in the city of Wrocław (Lower Silesia, Poland) and confirmed the occurrence of 10 species: Bombina bombina, Bufo bufo, Bufotes viridis, Hyla arborea, Pelobates fuscus, Pelophylax esculentus complex, Rana arvalis, Rana temporaria, Lissotriton vulgaris and Triturus cristatus. Among all studied sites, the most common were P. esculentus complex (146 occupied sites, $63.2 \%)$ and B. bufo $(119,51.5 \%)$, while the rarest was $P$. fuscus $(8,3.5 \%)$. The number of species at a single site varied from 0 (28 sites, 12.1\%) to 9 (1 site, $0.4 \%)$. Frequency and mean amphibian species richness reached $87.9 \%$ and $2.7 \pm 1.9$, respectively. The composition of amphibian species did not change in comparison to previous studies conducted in the years 1997-2009, but declining trends in five species (B. bombina, B. viridis, H. arborea, P. esculentus complex, P. fuscus) were observed (28 compared sites). The results revealed that the permanency of ponds, their occurrence in the vicinity of river valleys, and a high ratio of watercourse length and green area around ponds are positively correlated and have a significant influence on amphibian species richness within the city. Thus, these identified factors should be considered in the course of sustainable urban planning in order to avoid potential conflicts between nature conservation and urban development.
\end{abstract}

Keywords Amphibians · Lower Silesia · Poland · Urban habitat · Urbanisation

\section{Introduction}

Urbanisation and progressive changes in land use are considered to exert some of the strongest influences on amphibian populations worldwide. Adverse human activities, such

Electronic supplementary material The online version of this article (https://doi.org/10.1007/s11252-019-00912-3) contains supplementary material, which is available to authorized users.

Krzysztof Kolenda

krzysztof.kolenda@uwr.edu.pl

1 Ligota Mała, Poland

2 Amphibian Biology Group, Department of Evolutionary Biology and Conservation of Vertebrates, University of Wrocław, Sienkiewicza 21, 50-335 Wroclaw, Poland

3 Institute of Biology, Wrocław University of Environmental and Life Sciences, Kożuchowska 5B, 51-631 Wroclaw, Poland

4 Institute of Dendrology, Polish Academy of Sciences, Parkowa 5, 62-035 Kórnik, Poland

5 Wrocław, Poland

6 Cieszyn, Poland as urban expansion, development of dense road networks without provision of compensatory solutions, and increased runoff contribute to the widespread loss or degradation of habitats, water pollution, isolation, and other unrecognised threats (see Beebee and Griffiths 2005; Cushman 2006; Hamer and McDonnell 2008 for review). Consequently, these may lead to the drastic decline or even extinction of local populations of the most vulnerable species. Given the spread of invasive species and pathogens (such as chytrid fungi and ranaviruses) and climate change, the situation of amphibians appears to be critical worldwide (Corbett 1989; Collins and Storfer 2003; Pounds et al. 2006). Thus, the observed decline of this group of vertebrates may constitute a symbol of biodiversity loss due to anthropogenic pressure (Wake and Verdenburg 2008).

Amphibians are particularly vulnerable to adverse changes in their habitats during both the aquatic and terrestrial life stages. Eggs, larvae, and tadpoles remain in streams, ponds, and wetlands for months or even a full year. Following metamorphosis, juveniles are often dispersed from their natal ponds (e.g. Sinsch 1992), while adults of many frog, toad, and salamander species migrate seasonally between terrestrial (where they hide or hunt) and aquatic (where they breed) habitats (Vos and Stumpel 1996; Vos et al. 2001; Semlitsch and Bodie 2003). Therefore, the quality of the 
environment, both in and around breeding sites, is likely to be an important determinant of amphibian persistence in greatly altered urban landscapes (Semlitsch and Bodie 2003; Becker et al. 2007).

Current data on the occurrence of amphibians in European urban areas is still insufficient. Although the faunistic approach is still predominant, studies are increasingly being focused on the influence of habitat features on amphibian richness and distribution (Mollov 2011; Herczeg et al. 2012; Pulev and Sakelarieva 2013; Holtmann et al. 2017). Knowledge about amphibian populations living in Poland's biggest cities appears comparatively ample (e.g. Mazgajska 2008; Chętnicki et al. 2010; Najbar 2010; Budzik et al. 2013; Kaczmarek et al. 2014).

Among approximately 20 studied cities, long-term population trends have been analysed in only four, i.e. Poznań, Cracow, Warsaw, and Zielona Góra (Najbar et al. 2005; Mazgajska 2008; Budzik et al. 2013; Kaczmarek et al. 2014). However, in all of them, a gradual decline in the number of amphibian populations or their breeding sites, or even their total disappearance, has been observed. For instance, over recent decades Poznań and Zielona Góra have lost 20\% and $40 \%$ of their amphibian breeding sites, respectively (Najbar et al. 2005; Kaczmarek et al. 2014). However, the precise factors limiting the occurrence of these animals in urban areas, apart from breeding site losses, are still poorly understood (Najbar et al. 2005; Chętnicki et al. 2010; Sołtysiak and Dąbrowska 2014).

A study of the occurrence of amphibians in Wrocław was conducted during the years 1997-2009 by Ogielska and Kierzkowski (2010). Although the authors concerned only 31 breeding sites, they found 11 taxa (or 10, if $P$. ridibundus and $P$. esculentus were classified together as $P$. esculentus complex). Among these, changes in species composition in consecutive years were observed for only three sites, including one pond where fluctuations in the number of species and the sizes of populations were detected between 1993 and 2015 (Ogielska and Kierzowski 2010; Kolenda et al. 2017).

In this paper we present a complex study of amphibian occurrence and distribution in the city of Wrocław. Our aims were as follows: (i) to determine amphibian species richness (ASR) and the frequency of amphibians in occupied habitats within the city's administrative borders; (ii) to compare current data with the previous results obtained by Ogielska and Kierzkowski (2010); (iii) to test the influence of urbanisation on the ASR and distribution of amphibians. We hypothesise that species composition: (i) has changed in comparison with that reported in the study of Ogielska and Kierzkowski (2010) due to progressive urbanisation; (ii) is positively correlated with pond locations in river valleys, which constitute a significant ecological corridor for amphibians; (iii) is positively correlated with a large share of green areas within the surroundings of ponds, considered as both terrestrial and wintering habitats.

\section{Material and methods}

\section{Study area and sampling}

Wrocław, the largest city in south-western Poland $\left(51^{\circ} 6^{\prime}\right.$ $\left.36.50^{\prime \prime} \mathrm{N}, 17^{\circ} 1^{\prime} 55.33^{\prime \prime} \mathrm{E}\right)$ with an area of $293 \mathrm{~km}^{2}$ and a population of almost 638,000 people, is situated in lowlands approximately $107-143 \mathrm{~m}$ a. s. 1 . The city is located in the Oder River Valley; the river, along with its canals, is supported by four major tributaries, Bystrzyca, Ślęza, Oława, and Widawa, and several smaller tributaries. Wrocław is characterised by a Marine West Coast climate (according to the Köppen climate classification), with a mean annual temperature of $8.9^{\circ} \mathrm{C}$ and mean annual precipitation of $584 \mathrm{~mm}$ (www.weatherbase.com).

Based on available maps obtained from a governmental portal (Geoportal 2, www.geoportal.gov.pl) and personal field observations (referring to ponds not found on the maps), a total of 269 ponds were identified within the boundaries of the city (for detailed distributions of particular ponds, see Fig. S1). The majority include human-made ponds such as post-mining ponds, fish ponds, swimming/ recreational ponds, park ponds, and concrete water reservoirs for firefighting, etc.; only some are natural or semi-natural, i.e. oxbows or stormwater. In all, 231 ponds were chosen for further inventory and detailed analysis (Fig. 1; Table S1). The remaining 38 ponds were excluded from analyses and classified as not informative for the study because we were unable to obtain permission from their owners to enter their property or because, in the case of two ponds in the Botanical Garden, amphibians had been artificially introduced (Table S2).

The study was conducted from March to July 2016. We followed the methodology adapted for native amphibians (Mazgajska 1996; Makomaska-Juchiewicz and Baran 2012). All ponds were checked three to five times; visual and acoustic observations were made along their shorelines, both at night (using an electric torch) and during the day. Due to the large number of selected ponds, we were unable to estimate exact numbers of individuals per pond. Instead, we focused on species composition, identified directly based on: (i) external features of adult individuals, tadpoles, larvae, and egg clutches; and (ii) mating calls of anuran males. When necessary for identification, selected individuals were caught by hand or with the use of herpetological nets. Amphibians were released each time immediately after identification or photographic documentation. All taxa of water frogs were collectively classified as Pelophylax esculentus complex due to their high hybridisation rate (Berger 1973), as in earlier studies (e.g. Herczeg et al. 2012; Kaczmarek et al. 2014).

Amphibian species richness (ASR) was calculated as the total number of detected amphibians in a given pond or in all studied ponds (Houlahan and Findlay 2003). 


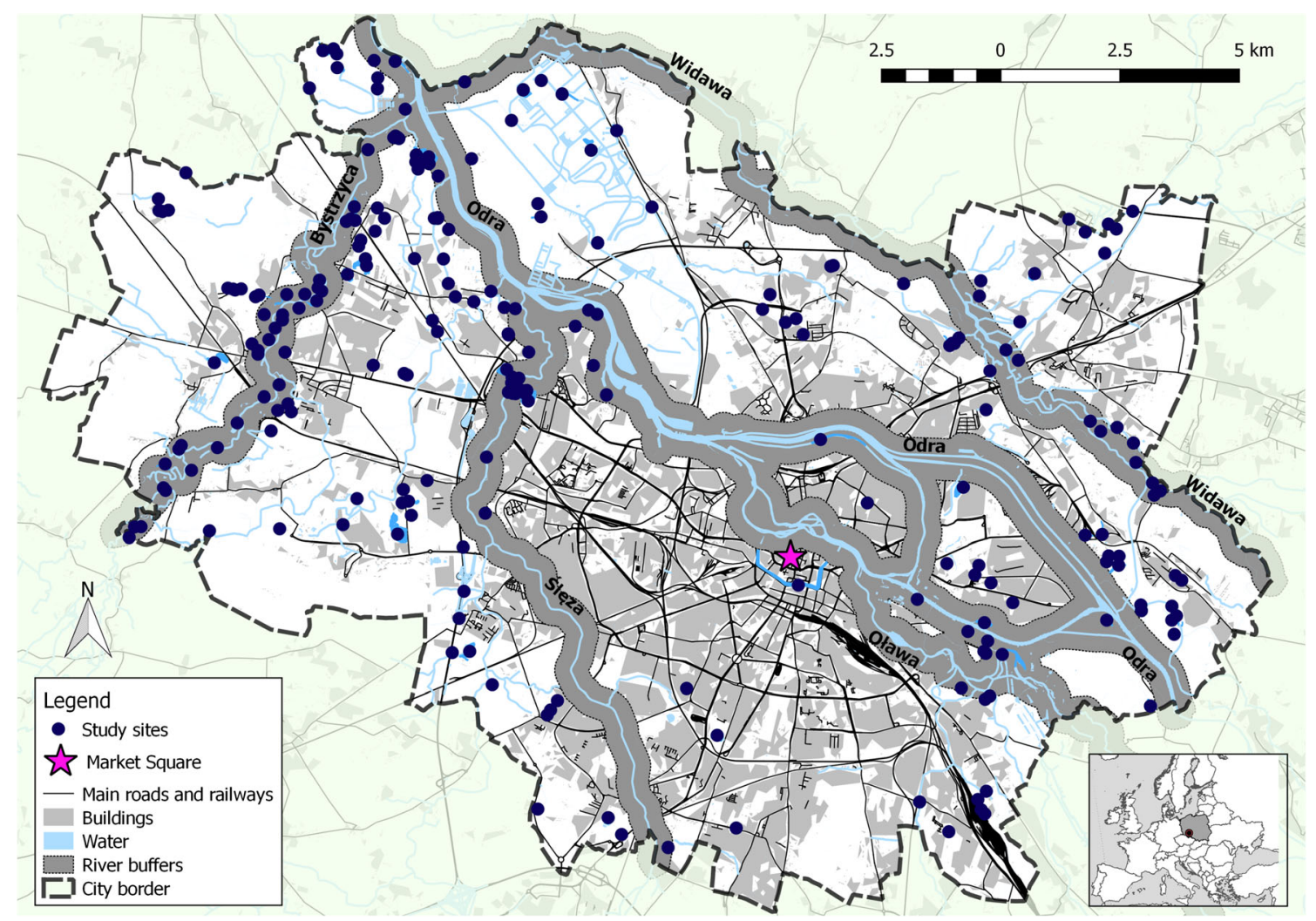

Fig. 1 Localisation of selected ponds in the city of Wrockaw

\section{Comparison with previous data}

Ogielska and Kierzkowski (2010) surveyed 31 amphibian breeding sites in Wrocław. However, three of these were not informative. In one case, the pond could not be identified in the field a second time; another was located in a private area which we were unable to obtain permission to enter; a third was located in the Botanical Garden with introduced populations (see above). Thus, 28 ponds were used for further comparison. ASR and frequency of amphibian's occurrence were calculated for both studied periods. Due to our different methodological approach, we compared only mean ASR in each pond using a pairwise Student's $t$ test in STATISTICA 13.1 software (StatSoft, USA). Additionally, for each species, we calculated the number of extinctions, survival and colonisation events between compared studies.

\section{Environmental characteristics}

We selected 11 traits to characterise ponds and the urbanisation level of the surrounding habitats (Table 1). The size of each pond, the distance between them and the Wroclaw Market Square (city centre) as well as to the nearest watercourse were estimated using QGIS ver. 2.18.1 (Quantum GIS Development Team 2016). The permanency of ponds (either permanent, including those that had partially dried out, or temporary) was determined on the basis of observations conducted during the period between March-July 2016. Assignment of pond locations to river valleys was carried out according to Semlitsch and Bodie (2003), i.e. within a buffer $339 \mathrm{~m}$ wide, including both riverbanks, around each of the five main rivers mentioned above. We used the same value to determine the buffer around shoreline of each pond and then calculated the following parameters within that buffer: 1) length of roads; 2) length of watercourses; 3 ) share of areas occupied by buildings; and 4) share of green areas (forest, green wasteland, meadow etc.) in relation to total area. We also calculated number of watercourses in each buffer. Variables were obtained from OpenStreetMap (www. openstreetmap.org) and the Wrocław Spatial Information System (www.geoportal.wroclaw.pl). Prior to calculations, information was checked within all buffers manually using orthoimagery available from the Wrocław Spatial Information System, and Google Earth ver. 7.3.2.5491 (Google Inc.). In cases where missing objects were identified, they were added manually; only updated files were used in subsequent analyses. The final parameter, human population density around each pond, was determined based on the allocation of each study site to one of 579 statistical regions of the city (data was obtained from the 2017 demographic data for the City of Wrocław, www. geoportal.wroclaw.pl). GIS operations were carried out in QGIS and R (R Core Development Team), using the 'raster' and 'rgdal' packages (Bivand et al. 2016; Hijmans 2016). 
Table 1 The environmental parameters used for the description of ponds and the urbanisation level of the surrounding habitats

\begin{tabular}{|c|c|c|c|c|c|}
\hline Variable & Abbreviation & Values & Mean & $\begin{array}{l}\text { Mean } \\
\text { ASR }\end{array}$ & SD \\
\hline Size of pond [ha] & p.size & $0.0005-13.2$ & 0.65 & - & 1.47 \\
\hline Distance from the city centre $[\mathrm{km}]$ & dist.city.ctr. & $0.61-15.23$ & 8.91 & - & 3.05 \\
\hline Distance to the nearest watercourse $[\mathrm{km}]$ & dist.water. & $0-3.29$ & 0.689 & - & 0.754 \\
\hline \multirow[t]{2}{*}{ Pond permanency } & \multirow[t]{2}{*}{ p.perm. } & $\begin{array}{l}\text { Permanent } \\
\qquad(N=210)\end{array}$ & - & 2.88 & 1.97 \\
\hline & & $\begin{array}{r}\text { Temporary } \\
(N=21)\end{array}$ & - & 1.71 & 1.10 \\
\hline \multirow[t]{2}{*}{ Pond occurrence in river valley } & \multirow[t]{2}{*}{ occ.rv. } & Yes $(N=95)$ & - & 3.19 & 2.11 \\
\hline & & No $(N=136)$ & - & 2.39 & 1.73 \\
\hline $\begin{array}{l}\text { Mean length of roads in the buffer in } \\
\text { relation to its area }\end{array}$ & mean.1.rd. & $0.001-0.020$ & 0.008 & - & 0.004 \\
\hline $\begin{array}{l}\text { Mean length of watercourses in the buffer in } \\
\text { relation to its area }\end{array}$ & mean.l.water. & $0-0.019$ & 0.004 & - & 0.003 \\
\hline $\begin{array}{l}\text { Mean share of area with buildings in the } \\
\text { buffer in relation to its area }\end{array}$ & mean.s.bldg. & $0-0.262$ & 0.043 & - & 0.049 \\
\hline $\begin{array}{l}\text { Mean share of green areas in the buffer in } \\
\text { relation to its area }\end{array}$ & mean.s.green. & $0.072-0.998$ & 0.686 & - & 0.197 \\
\hline Number of watercourses in the buffer & no.water & $0-107$ & 10 & - & 22.1 \\
\hline Human population density [people $/ \mathrm{km}^{2}$ ] & pop.dens. & $22-10,554$ & 863.73 & - & 1063.69 \\
\hline
\end{tabular}

Maps were obtained in ETRS89/Poland CS2000 zone 6 (EPSG: 2177); and in cases where it was not their native projection they were reprojected to match it.

Prior to carrying out statistical tests, we checked spatial autocorrelations between selected ponds with reference to our tested variables. We found that only occurrence of $P$. fuscus showed non-significant spatial autocorrelation (Moran's I $=0.018, p=0.134$; Table S3).

We used a generalised linear model with Poisson error and log link function to determine the effect of environmental variables on ASR. Additionally we used generalised linear models with binomial error and logit link function to determine the effect of environmental variables on the probability of the occurrence of each amphibian species (Table 2). In each model (except the probability of $P$. fuscus) we included latitude and longitude as covariates in order to address spatial autocorrelation (according to Dylewski et al. 2019). In each model we used all of the above-mentioned fixed-effect variables (Table 1). To standardise explanatory variables we used a Z-score function. To avoid multicollinearity, we excluded 2 variables (mean.l.rd. and mean.s.bldg.) from each model. Multicollinearity in the remaining explanatory variables was not excessive in any model (VIF $<2)$. Final validation of the models was carried out using diagnostic plots in both cases.

For model selection we used the Akaike's Information Criterion adjusted for small sample sizes (AICc), to identify the most parsimonious model from each candidate set. We ranked all possible model combinations according to their $\triangle \mathrm{AICc}$ values and used models with the lowest AICc, along with the associated weight values (the probability that a given model is the best), as those best describing the data. We considered candidate models differing by less than 2 AICc units $(\triangle \mathrm{AICc}<2.0)$ to be equally informative and subject to possible model averaging. For averaging, we used models with weights with $\triangle \mathrm{AICc}$ values below 4 (Burnham and Anderson 2002).

To check differences in ASR between permanent and temporary ponds and between ponds in and outside river valleys, we used the Mann-Whitney U test.

All analysis was carried out in R 3.3.2 ( $\mathrm{R}$ Core Development Team 2016). Spatial autocorrelation was calculated using the 'ape' package (Paradis and Schliep 2018). Model selection was accomplished using the 'MuMIn' package (Barton 2016). Data visualisation was carried out in the 'ggplot2' package (Wickham 2009).

Table 2 Frequency of the occurrence of amphibians in studied sites in the city of Wrocław $(N=231)$

\begin{tabular}{ll}
\hline Species & $\begin{array}{l}\text { Number of } \\
\text { occupied ponds }\end{array}$ \\
\hline Pelophylax esculentus complex & $146[63.2 \%]$ \\
Bufo bufo & $119[51.5 \%]$ \\
Hyla arborea & $64[27.7 \%]$ \\
Rana temporaria & $63[27.3 \%]$ \\
Rana arvalis & $58[25.1 \%]$ \\
Lissotriton vulgaris & $52[22.5 \%]$ \\
Triturus cristatus & $46[19.9 \%]$ \\
Bombina bombina & $39[16.9 \%]$ \\
Bufotes viridis & $24[10.4 \%]$ \\
Pelobates fuscus & $8[3.5 \%]$ \\
\hline
\end{tabular}




\section{Results}

Ten amphibian species ( 8 anurans and 2 urodeles) were observed in the city of Wrocław: fire-bellied toad Bombina bombina (Linnaeus, 1761), tree frog Hyla arborea (Linnaeus, 1758), common toad Bufo bufo (Linnaeus, 1758), green toad Bufotes viridis (Laurenti, 1768), common frog Rana temporaria (Linnaeus, 1758), moor frog $R$. arvalis (Nilsson, 1842), water frogs Pelophylax esculentus complex, common spade-foot Pelobates fuscus (Laurenti, 1768), smooth newt Lissotriton vulgaris (Linnaeus, 1758) and great crested newt Triturus cristatus (Laurenti, 1768). The most widespread were Pelophylax species (frequency 63.2\%) and B. bufo $(51.5 \%)$, whereas P. fuscus was the rarest (3.5\%) (Table 2). Total frequency of amphibians in studied ponds and mean ASR reached $87.9 \%$ and $2.7 \pm 1.9$ (median $=2$ ), respectively. ASR at single sites varied from $0(12.1 \%)$ to $9(0.4 \%)$, and the majority of studied ponds $(48 \%)$ were represented by two or three species (see Table S4 for details). Detailed results of species occurrence in particular ponds are presented in Table S1.

A comparison of the present study with that conducted by Ogielska and Kierzkowski (2010) revealed that the composition of amphibian species had not changed over time. Mean ASR per sites $(N=28)$ studied in $1997-2009$ was $4.00 \pm 1.92($ median $=4)$, whereas in the present study this value reached $3.96 \pm 2.55$ (median $=4)$ (Fig. 2); the difference was not significant (pairwise Student's t test: $p=0.92$ ). ASR decreased in 11 ponds and increased in 9. Differences in ASR from pond to pond are shown in Fig. S2. Frequency of amphibians in ponds $(N=28)$ decreased slightly between compared periods, from 89.3 to $85.7 \%$. In the case of 5 species ( $B$. bombina, B. viridis, $H$. arborea, P. esculentus complex, P. fuscus) extinction events were more frequent than colonisation events, but in the remaining 5 species ( $B$. bufo, $R$. arvalis,

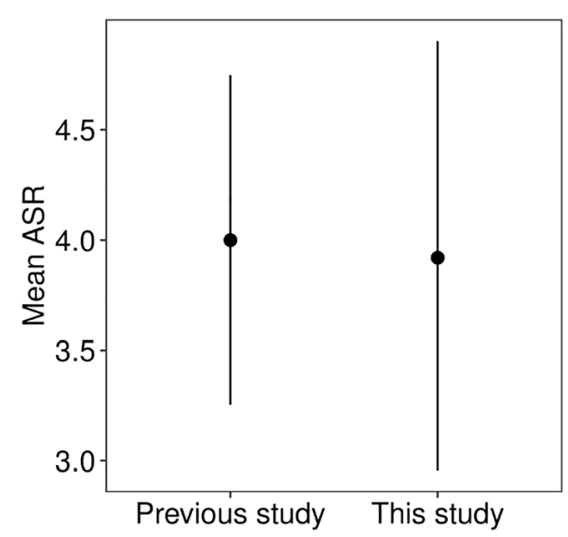

Fig. 2 Comparison of mean $( \pm 95 \%$ CI $)$ ASR in the previous study by Ogielska and Kierzkowski (2010) and this study
R. temporaria, L. vulgaris, T. cristatus) the trend was opposite (for details, see Fig. 3).

Generalised linear model revealed that four variables had a significant positive impact on ASR in the studied ponds: pond periodicity, the occurrence of ponds in river valleys, and ratios of watercourse length and green area to buffer area (Table 3). Based on the Akaike's Information Criterion for model selection, 11 models of the ASR were considered equally good, explaining 19$20 \%$ of the variation (Table S5).

Pond permanency had a significantly positive impact on the probability of the occurrence of B. bufo, $P$. esculentus complex, R. temporaria, and L. vulgaris, but a negative influence on $B$. viridis. B. bombina and $T$. cristatus were significantly less common in ponds characterised by greater distances to the nearest river; moreover, greater population density had a significantly negative impact on $B$. bombina. Mean length of watercourses in the buffer was a significant predictor for the probability of the occurrence of $B$. bombina, B. viridis, and $P$. fuscus, whereas mean share of green areas in the buffer constituted such a predictor for $H$. arborea, R. temporaria, L. vulgaris, and T. cristatus. Pond occurrence in river valley significantly influenced the occurrence of $H$. arborea, $R$. temporaria, and L. vulgaris, whereas number of watercourses influenced $P$. fuscus (Table S6-7).

We found significant differences in ASR between permanent and temporary ponds (Mann-Whitney $U$ test: 1528.5, $p=0.018$ ), and between occurrence or absence of river valleys (Mann-Whitney $\mathrm{U}$ test: 5033.5, $p=$ 0.004).

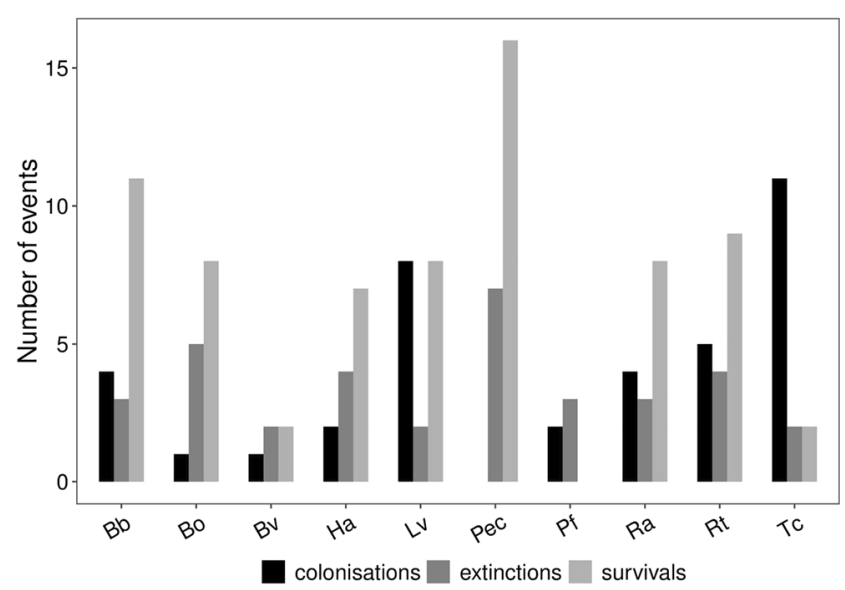

Fig. 3 Number of extinction, survival, and colonisation events for each species in 1997-2009 [studied by Ogielska and Kierzkowski (2010)] and $2016(N=28)$. Abbreviations of the species: $B b-$ Bombina bombina, Bb - Bufo bufo, Bv - Bufotes viridis, Ha - Hyla arborea, Pf - Pelobates fuscus, Pec - Pelophylax esculentus complex, Ra - Rana arvalis, RtRana temporaria, Lv-Lissotriton vulgaris, Tc - Triturus cristatus 
Table 3 Factors affecting the ASR in ponds. Statistically significant values are presented in bold

\begin{tabular}{lllll}
\hline Variables & Estimate & SE & $\begin{array}{l}\text { Z- } \\
\text { value }\end{array}$ & $p$ value \\
\hline Intercept & -27.772 & 62.99 & 0.44 & 0.660 \\
Dist.city.ctr. & 0.002 & 0.07 & 0.03 & 0.975 \\
Dyst.rv. & -0.077 & 0.06 & 1.21 & 0.226 \\
Latitude & 1.595 & 1.38 & 1.15 & 0.249 \\
Longitude & -0.717 & 0.58 & 1.24 & 0.215 \\
Mean.l.water. & $\mathbf{0 . 0 8 9}$ & $\mathbf{0 . 0 4}$ & $\mathbf{2 . 3 4}$ & $\mathbf{0 . 0 1 9}$ \\
Mean.s.green. & $\mathbf{0 . 1 9 4}$ & $\mathbf{0 . 0 5}$ & $\mathbf{3 . 7 3}$ & $<\mathbf{0 . 0 0 1}$ \\
Occ.rv. & $\mathbf{0 . 2 6 7}$ & $\mathbf{0 . 1 0}$ & $\mathbf{2 . 6 4}$ & $\mathbf{0 . 0 0 8}$ \\
P.area & 0.030 & 0.05 & 0.61 & 0.541 \\
P.perm. & $\mathbf{0 . 6 1 8}$ & $\mathbf{0 . 1 8}$ & $\mathbf{3 . 5 0}$ & $<\mathbf{0 . 0 0 1}$ \\
\hline
\end{tabular}

\section{Discussion}

\section{Amphibian species richness}

The results include total ASR (10) values similar to those recorded in other highly developed cities (of over 100,000 inhabitants) in Poland, ranging between 8 in Wałbrzych (Tomalka-Sadownik and Rozenblut-Kościsty 2010) to 11 in Białystok (Chętnicki et al. 2010). Mean ASR values found in Polish cities varied from 1.54 in Wałbrzych (TomalkaSadownik and Rozenblut-Kościsty 2010) to 5.16 in Zielona Góra (Najbar 2010). The value for Wrocław (2.73) fell within this range. Similarly, $88 \%$ of ponds were inhabited by amphibians; this value ranged from e.g. $83.5 \%$ in Olsztyn (Nowakowski et al. 2010) to 94.3\% in Białystok (Chętnicki et al. 2010) and 96\% in Zielona Góra (Najbar 2010). These results suggest that cities provide many suitable habitats for most of the lowland species occurring in Poland.

Our results only partially correspond to those of the previous study conducted in Wrocław by Ogielska and Kierzkowski (2010). All species observed in that study still occur within the city. In terms of the compared ponds, the mean ASR is almost the same and the total frequency is only slightly reduced. These findings are probably attributable to the short period elapsed between the two studies. However, the higher mean ASR in ponds selected by Ogielska and Kierzkowski (2010) in comparison to all ponds studied in 2016 may suggest that those ponds were not randomly chosen (i.e. high ASR bias), as the authors have admitted. We also noted an increased mean ASR in several ponds as the result of a high number of probable colonisation events by two newt species which are difficult to detect in the field (e.g. Paterson 2018); thus this result may suggest that they were overlooked in the past. However, the similar number of ponds with reduced or increased ASR, along with the same number of species with more frequent colonisation or extinction events may suggest that amphibian populations function as meta-communities in urban areas, i.e. individual sites are colonised and go extinct frequently, but the population as a whole persists (see also Parris 2006). However, this hypothesis requires further long-term study.

It also appears that ASR is an insufficient indicator for the assessment of the influence of urbanisation on amphibians, since, even high ASR value, population size or frequency for a particular species may be significantly reduced. Indeed, in other studied cities in Poland, a significant decrease in amphibian frequency was noticed for many species over at least the last 20 years, while ASR did not change significantly (Kaczmarek et al. 2014; Budzik et al. 2013). Thus, to calculate the effect of urbanisation on amphibian populations, the population size per pond as well as the frequency of each species should also be taken into account.

Pelophylax species and B. bufo were the most common species in the city of Wrocław. This finding is in line with the majority of the other studied cities (Chętnicki et al. 2010; Najbar 2010; Budzik et al. 2013; Kaczmarek et al. 2014). Both are known to be adaptable to heterogeneous habitats, including urban areas (Pavignano et al. 1990; Berger 2008; Mollov 2011; Budzik et al. 2013). The relatively low share of $R$. temporaria is an unexpected result, as this is a frequent species in all of the large Polish cities that have been studied (e.g. Najbar 2010; Budzik et al. 2013; Kaczmarek et al. 2014). However, an unexplained decline in the population of this species around the city of Wrocław has been observed for over a decade (M. Ogielska pers. comm., K. Kolenda unpubl. data). $H$. arborea and T. cristatus were among the rarest species in the city of Wrocław; their frequencies were relatively high in comparison to other big cities. Moreover, $H$. arborea is absent from many other cities (Najbar 2010; Tomalka-Sadownik and Rozenblut-Kościsty 2010; Budzik et al. 2013; Kaczmarek et al. 2014). We suppose that this is the result of the existence of many suitable habitats for these species in Wrocław, in particular a large share of green areas directly near the ponds. Furthermore, breeding habitats in the river valley enable movement between ponds (Vos and Stumpel 1996; Hartel et al. 2007). B. viridis was one of the rarest species, found only in $10 \%$ of ponds. This species, considered as rapid coloniser of pioneer habitats, is well adapted to settle in ponds in urban environments that have undergone changes due to human influence (Ensabella et al. 2003; Kühnel and Krone 2003; Indermaur et al. 2009; Zawadzki et al. 2017). However, the frequency of this species in the largest cities in Poland reached approximately $10 \%$ or less, and population sizes were usually small (Chętnicki et al. 2010; TomalkaSadownik and Rozenblut-Kościsty 2010). Moreover, over the past 20-25 years, a drastic decline in the number of green toad populations was observed in Cracow and Poznań, where frequency of this species decreased from $54 \%$ to $10 \%$ and from $55 \%$ to $20 \%$, respectively (Budzik et al. 2013; 
Kaczmarek et al. 2014). The situation of B. viridis is also uncertain in other European cities. In Szeged (Hungary), $11 \%$ of studied sites were inhabited by this species; in the urbanised area surrounding Milan (Italy), only 3.5\%, (Ficetola and De Bernardi 2004; Herczeg et al. 2012). A drastic loss of population has also been recorded in some parts of Berlin (Kühnel and Krone 2003).

\section{Factors limiting the occurrence of amphibians}

The general distributional pattern of amphibians in the city of Wrocław is associated with the occurrence of ponds in river valleys as well as with the length of rivers, the size of green areas in their immediate surroundings, and pond permanency. We obtained similar results by means of examining the probability of the occurrence of particular species separately. These results were predictable, especially given that urban development often causes habitat fragmentation and has negative effects on biodiversity, including amphibian assemblages (Vos and Chardon 1998; Beninde et al. 2015). Although various species may reveal different responses to isolation, generally this factor reduces their numbers (Ficetola and De Bernardi 2004; Parris 2006). Thus, a network of ponds near river valleys favours the migration of amphibians and promotes their species richness. Similarly, a large share of green areas surrounding ponds can limit the need for long-distance migrations from wintering sites to breeding and feeding sites and may provide stable conditions for metamorphs. Dense road networks near breeding sites may reduce ASR (Herczeg et al. 2012). In Poland, road mortality affects many species, primarily B. bufo (Elzanowski et al. 2009); this problem is observed around the periphery as well as in several localities within the boundaries of Wrocław (Orłowski et al. 2008; Elzanowski et al. 2009; Najbar et al. 2019).

The permanency of ponds is also significant. Not only did amphibians migrate to permanent breeding ponds, but mating individuals were observed in rapidly disappearing backwaters formed in wastelands, or in puddles; however, more species were found in the former group of sites. Permanent water habitats support the highest levels of amphibian diversity, because many larvae are transformed into terrestrial metamorphs only in the late spring or summer (Skelly et al. 1999; Paton and Crouch 2002). On the other hand, such ponds support fish abundance, which reduces the breeding success and even the occurrence of amphibians (Hartel et al. 2007; Kloskowski 2011). Among all of the species found in this study, L. vulgaris, $T$. cristatus, $H$. arborea, $P$. fuscus, and B. viridis seem to be the most vulnerable to fish predation and competition (Ensabella et al. 2003; Ficetola and De Bernardi 2004; Kloskowski 2011).

In accordance with the results of this study, we suggest to apply some solutions that may reconcile the existence of amphibians with urban conditions and thus prevent their disappearance. These are: (i) protection of the most valuable breeding sites (those with 6 or more species) or groups of ponds, with special attention paid to those occurring in river valleys which provide the potential for dispersion; (ii) limitation of human interference in the buffer zone, along with maintenance of neighbouring green areas (Semlitsch and Bodie 2003); (iii) creation of additional ponds at sites possessing features of ecological continuity; (iv) avoidance of the introduction of fish and non-native species; (v) scheduling of any maintenance work (including elimination of fish and non-native species) in ponds and their surrounding areas either before or after amphibian breeding season (Ensabella et al. 2003); (vi) continued monitoring of selected ponds, taking into account other parameters such as population size.

\section{Conclusions}

After comparison with data collected in the years 1997-2009 (Ogielska and Kierzkowski 2010), our study did not confirm the loss of any amphibian species; however, declining trends were observed in several species. Differences in methodology, as well as small sample sizes and the assumed strong ASR bias of the previous study, prevented us from drawing more detailed conclusions. We suggest that ASR is too general index for investigation of the long-term effects of the urbanisation on amphibians. Hence, other parameters, such as differences in the sizes of populations in selected ponds, are required for estimates in studies of this kind. Our study also confirmed that the occurrence of amphibian populations in the city of Wrocław depends on pond permanency, the location of ponds near river valleys, and ratios of watercourse length as well as of green, undisturbed areas to total area surrounding breeding pond. Accordingly, in order to maintain amphibian populations in Wrocław, city planning needs to consider ponds (especially those located in river valleys) and the natural areas surrounding them.

Acknowledgements We thank Marta Kubisiak for help with field work, Maria Ogielska and Mikołaj Kaczmarski for their valuable comments to the manuscript. The project was approved by the Regional Directorate for Environmental Protection in Wrocław (permit no. WPN.6401.131.2016.IW).

Open Access This article is distributed under the terms of the Creative Commons Attribution 4.0 International License (http:// creativecommons.org/licenses/by/4.0/), which permits unrestricted use, distribution, and reproduction in any medium, provided you give appropriate credit to the original author(s) and the source, provide a link to the Creative Commons license, and indicate if changes were made.

\section{References}

Bartoń K (2016) MuMIn: multi-model inference. R package version 3:23 http://CRAN.Rproject.org/package=MuMIn 
Becker CG, Fonseca CR, Haddad CFB, Batista RF, Prado PI (2007) Habitat split and the global decline of amphibians. Science 5857: $1775-1777$

Beebee TJC, Griffith RA (2005) The amphibian decline crisis: a watershed for conservation biology? Biol Conserv 125:271-285. https:// doi.org/10.1016/j.biocon.2005.04.009

Beninde J, Veith M, Hochkirch A (2015) Biodiversity in cities needs space: a meta-analysis of factors determining intra-urban biodiversity variation. Ecol Lett 8:581-592. https://doi.org/10.1111/ele. 12427

Berger L (1973) Systematics and hybridization in European green frogs of Rana esculenta complex. J Herpetol 7:1-10

Berger L (2008) European green frogs and their protection. Ecological Library Foundation in Poznań, PRODRUK

Bivand R, Keitt T, Rowlingson R (2016) Rgdal: bindings for the geospatial data abstraction library. R package version 1:2-5 https:// CRAN.R-project.org/package $=$ rgdal

Budzik KA, Budzik KM, Żuwała K (2013) Amphibian situation in urban environment - history of the common toad Bufo bufo in Kraków (Poland). Ecol Quest 18:73-77

Burnham KP, Anderson DR (2002) Model Selection and Multimodel Inference. 2nd ed. Springer, New York

Chętnicki W, Siwak P, Mazgajska J, Mazgajski T (2010) Amphibians of Białystok. Fragm Faun 53:245-264

Collins JP, Storfer A (2003) Global amphibian declines: sorting the hypotheses. Divers Distrib 9:89-98. https://doi.org/10.1046/j.14724642.2003.00012.x

Corbett AS (ed) (1989) Conservation of European reptiles and amphibians. Christopher Helm, London, U.K.

Cushman SA (2006) Effects of habitat loss and fragmentation on amphibians: a review and prospectus. Biol Conserv 128:231-240. https:// doi.org/10.1016/j.biocon.2005.09.031

Dylewski $Ł$, Maćkowiak $Ł$, Banaszak-Cibicka W (2019) Are all urban green spaces a favourable habitat for pollinator communities? Bees, butterflies and hoverflies in different urban green areas. Ecol Entomol. https://doi.org/10.1111/een.12744

Elzanowski A, Ciesiołkiewicz J, Kaczor M, Radwańska J, Urban R (2009) Amphibian road mortality in Europe: a meta-analysis with new data from Poland. Eur J Wildlife Res 55:33-43. https://doi.org/ 10.1007/s10344-008-0211-X

Ensabella F, Loriga S, Formichetti P, Isotti R, Sorace A (2003) Breeding site selection of Bufo viridis in the city of Rome (Italy). AmphibiaReptilia 24:396-400.https://doi.org/10.1163/ 156853803322440853

Ficetola GF, De Bernardi F (2004) Amphibians in a human-dominated landscape: the community structure is related to habitat features and isolation. Biol Conserv 119:219-230. https://doi.org/10.1016/j. biocon.2003.11.004

Hamer AJ, McDonnell MJ (2008) Amphibian ecology and conservation in the urbanizing world: a review. Biol Conserv 141:2432-2449. https://doi.org/10.1016/j.biocon.2008.07.020

Hartel T, Nemes S, Cogălniceanu D, Öllerer K, Schweiger O, Moga CI, Demeter L (2007) The effect of fish and aquatic habitat complexity on amphibians. Hydrobiologia 583:173. https://doi.org/10.1007/ s10750-006-0490-8

Herczeg D, Gallé R, Molnár N (2012) Effects of urbanization on the occurence of Anura assemblages in the city of Szeged (Hungary). Tiscia 39:3-8

Hijmans RJ (2016) Raster: geographic data analysis and modeling. R package version 2:5-8 https://CRAN.R-project.org/package=raster

Holtmann L, Philipp K, Becke C, Fartmann T (2017) Effects of habitat and landscape quality on amphibian assemblages of urban stormwater ponds. Urban Ecosyst 20:1249-1259. https://doi.org/ 10.1007/s11252-017-0677-y

Houlahan JE, Findlay CS (2003) The effects of adjacent land use on wetland amphibian species richness and community composition.
Can J Fish Aquat Sci 60:1078-1094. https://doi.org/10.1139/f03095

Indermaur L, Gehring M, Wehrle W, Tockner K, Naef-Daenzer B (2009) Behavior-based scale definitions for determining individual space use: requirements of two amphibians. Am Nat 173:60-71

Kaczmarek JM, Kaczmarski M, Pędziwiatr K (2014) Changes in the batrachofauna in the city of Poznań over 20 years. In: Böhner J, Indykiewicz P (eds.) Urban Fauna. Animal, man, and the City interactions and relationships. ArtStudio, Bydgoszcz, pp. 169-178

Kloskowski J (2011) Impact of common carp Cyprinus carpio on aquatic communities: direct trophic effects versus habitat deterioration. Fund Appl Limnol 178:245-255

Kolenda K, Kuśmierek N, Migdał P, Gruszczyński P, Moliński P, Ogielska M (2017) Amphibians of the pond near the Pautscha street in Wrocław - state of population, threats, protection. Przegląd Przyrodniczy 28:63-73 [in Polish with English summary]

Kühnel KD, Krone A (2003) Bestandssituation, Habitatwahl und Schutz der Wechselkröte ( $B$ ufo viridis) in Berlin Grundlagenuntersuchungen für ein Artenhilfsprogramm in der Großstadt. Mertensiella 14:299-315

Makomaska-Juchiewicz M, Baran P (eds) (2012) Monitoring gatunków zwierząt. Przewodnik metodyczny. Część III. GIOŚ, Warszawa

Mazgajska J (1996) Distribution of amphibians in urban water bodies [Warsaw agglomeration, Poland]. Ekologia Polska 44:245-257

Mazgajska J (2008) Zmiany składu gatunkowego batrachofauny Warszawy w ostatnich piętnastu latach, w związku z przekształceniami środowisk rozrodczych. In: Zamachowski W. (ed.). Biologia Płazów i Gadów - Ochrona Herpetofauny. IX Ogólnopolska Konferencja Herpetologiczna, 22-23.09.2008, Kraków. Wydawnictwo Naukowe Akademii Pedagogicznej, Kraków, pp. 66-67

Mollov I (2011) Habitat distribution of the amphibians and reptiles in the city of Plovdiv, Bulgaria. Biharean Biologist 5:25-31

Najbar A, Konowalik A, Frydlewicz M, Kisiel P, Kolenda K, Konowalik K, Starzecka A, Zaleśna A (2019) Amphibians of the city of Wrocław - threats and recommendations for conservation. Chrońmy Przyrodę Ojczystą 75(2):98-112 [in Polish with English summary]

Najbar B (2010) The occurrence of amphibians in Zielona Góra in 20052008. Fragm Faun 53:181-194

Najbar B, Szuszkiewicz E, Pietruszka T (2005) Amphibia in Zielona Góra and the disappearance of their sites located within the administrative borders of the town in the years 1974-2004. Przegląd Zoologiczny 49:155-166 [in Polish with English summary]

Nowakowski JJ, Górski A, Lewandowski K (2010) Amphibian communities in small water bodies in the city of Olsztyn. Fragm Faun 53: 213-231

Ogielska M, Kierzkowski P (2010) Long term data on the amphibians of Wrocław. Fragm Faun 53:195-212

Orłowski G, Ciesiołkiewicz J, Kaczor M, Radwańska J, Żywicka A (2008) Species composition and habitat correlates of amphibian road-kills in different landscapes of South-Western Poland. Pol J Ecol 56:659-671

Paradis E, Schliep K (2018) Ape 5.0: an environment for modern phylogenetics and evolutionary analyses in R. Bioinformatics 35:526-528

Parris KM (2006) Urban amphibian assemblages as metacommunities. J Anim Ecol 75:757-764. https://doi.org/10.1111/j.1365-2656.2006. 01096.x

Paterson E (2018) Changes in relative population size detection rates of great crested newts (Triturus cristatus) over time. Herpetology Notes 143:12-17

Paton PW, Crouch WB (2002) Using the phenology of pond-breeding amphibians to develop conservation strategies. Conserv Biol 16: 194-204. https://doi.org/10.1046/j.1523-1739.2002.00260.x 
Pavignano I, Giacoma C, Castellano S (1990) A multivariate analysis of amphibian habitat determinants in north western Italy. AmphibiaReptilia 11:311-324. https://doi.org/10.1163/156853890X00014

Pounds JA, Bustamante MR, Coloma LA, Consuegra JA, Fogden MPL, Foster PN, La Marca E, Masters KL, Merino-Viteri A, Puschendorf R, Ron SR, Sánchez-Azofeifa GA, Still CJ, Young BE (2006) Widespread amphibian extinctions from epidemic disease driven by global warming. Nature 439:161-167

Pulev A, Sakelarieva L (2013) Herpetofauna in the city of Blagoevgrad, South-Western Bulgaria. BioDiscovery 7:e8943

Quantum GIS Development Team (2016) Quantum GIS geographic information system. Open Source Geospatial Foundation Project. http://qgis.osgeo.org

R Core Team (2016) R: a language and environment for statistical computing. R Foundation for Statistical Computing, Vienna, Austria https://www.R-project.org/

Semlitsch RD, Bodie JR (2003) Biological criteria for buffer zones around wetlands and riparian habitats for amphibians and reptiles. Conserv Biol 17:1219-1228

Sinsch U (1992) Structure and dynamics of a natterjack toad metapopulation (Bufo calamita). Oecologia 90:489-499

Skelly DK, Werner EE, Cortwright SA (1999) Long-term distributional dynamics of a Michigan amphibian assemblage. Ecology 80:2326 2337
Sołtysiak M, Dąbrowska D (2014) Is there a space for amphibians in the area of Chorzów city and Sosnowiec city? In: Böhner J, Indykiewicz P (eds.) Urban Fauna. Animal, man, and the City - interactions and relationships. ArtStudio, Bydgoszcz, pp. 161-168

Tomalka-Sadownik A, Rozenblut-Kościsty B (2010) Amphibians of Wałbrzych. Fragm Faun 53:163-179

Vos CC, Chardon JP (1998) Effects of habitat fragmentation and road density on the distribution pattern of the moor frog Rana arvalis. $\mathrm{J}$ Appl Ecol 35:44-56

Vos CC, Stumpel AHP (1996) Comparison of habitat-isolation parameters in relation to fragmented distribution patterns in the tree frog (Hyla arborea). Landsc Ecol 11:203-214

Vos CC, Verboom J, Opdam PFM, Ter Braak CJF (2001) Toward ecologically scaled landscape indices. Am Nat 183:24-41

Wake DB, Vredenburg VT (2008) Are we in the midst of the sixth mass extinction? A view from the world of amphibians. Proc Natl Acad Sci U S A 105:11466-11473. https://doi.org/10.1073/pnas. 0801921105

Wickham H (2009) ggplot2: elegant graphics for data analysis. SpringerVerlag, New York

Zawadzki M, Flesch A, Kaczmarski M (2017) New breeding site of the green toad Bufotes viridis Laurenti, 1768 in the downtown of Poznań. Przegląd Przyrodniczy 28:113-118 [in Polish with English summary] 